\title{
In memoriam Ivanu Cifriću (1946. - 2018.)
}

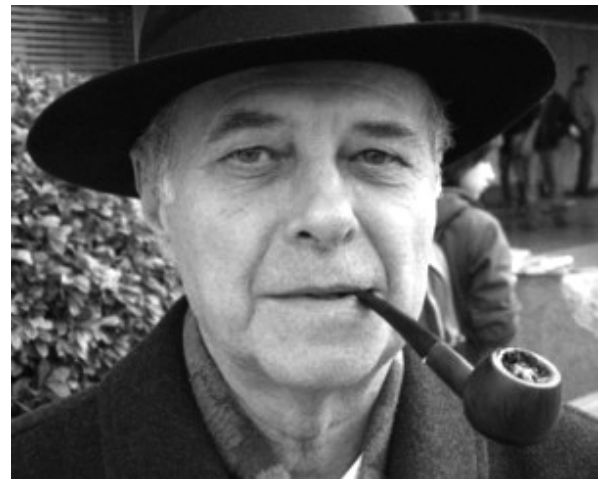

U studenom prošle godine napustio nas je naš dragi kolega, suradnik i prijatelj akademik Ivan Cifrić nakon duge bolesti, koju je godinama hrabro savladavao. Svih tih godina vrijedno je radio, vodio istraživanja i objavljivao članke i knjige.

Ivan Cifrić rođen je 22. siječnja 1946. godine u Petrijevcima, u Slavoniji. Diplomirao je sociologiju i filozofiju na Filozofskom fakultetu Sveučilišta u Zagrebu. Doktorirao je 1980. godine na istom fakultetu, gdje je, na Odsjeku za sociologiju, i proveo najveći dio radnog vijeka. Za redovitog člana Hrvatske akademije znanosti i umjetnosti, razred društvene znanosti, izabran je 2010. godine.

Vodio je brojne znanstvene projekte na svom matičnom fakultetu, među kojima su i projekti Ekološka svijest mladih (1986. - 1987.), Ekološki aspekti društvenog razvoja (1986. - 1990.), Socijalnoekološki aspekti razvoja (1990. - 1996.), Socijalnoekološki i modernizacijski procesi u Hrvatskoj (1996. - 2000.), Modernizacija i identitet hrvatskog društva (2002. - 2005.) te Sociokulturne integracije i razvoj (2007. - 2014.). Objavio je preko stotinu znanstvenih i stručnih radova u časopisima i zbornicima te više od 50 recenzija inozemnih knjiga. Objavio je petnaest knjiga: Revolucija i seljaštvo (1981.), Klasno društvo i obrazovanje (1984.), Ekološka svijest mladih (1987., koaut. B. Čulig), Ekološka adaptacija i socijalna pobuna (1990.), Ogledi iz sociologija obrazovanja (1990.), Napredak i opstanak (1994.), Bioetika (2000.), Moderno društvo i svjetski etos (2000.), Okoliš i održivi razvoj (2002.), Ruralni razvoj i modernizacija (2003.), Bioetička ekumena (2007.), Pojmovnik kulture i okoliša (2009.), Kultura i okoliš (2009. i 2012.), Leksikon socijalne ekologije (2012.) i Ekologija vremena i kultura zidova (2015.).

Bio je pokretač i urednik časopisa Socijalna ekologija (1992. - 2012.) i časopisne biblioteke Razvoj i okoliš (od 1994.), a također je bio i jedan od pokretača časopisa Revija za sociologiju.

Profesor Cifrić bio je i dugogodišnji suradnik na različitim znanstvenim projektima u Institutu za društvena istraživanja u Zagrebu. Osobito treba istaknuti njegovo sudjelovanje na znanstvenim projektima iz područja sociologije religije: Religijske promjene i vrijednosti u hrvatskom društvu (1996. - 2002.) te Društvene i religijske promjene u Hrvatskoj (2003. - 2006.). Sjećamo ga se kao odgovornog i predanog suradnika, pamtimo ga kao ozbiljnog znanstvenika koji je u područjima kojima se 
bavio otvarao nove vidike i koji nas je pomalo ljutio navikom da sve obaveze i sve tekstove uvijek završi prvi i uvijek prije roka.

Napustio nas je prerano. Zahvalni smo mu što je bio dio naših života, zahvalni smo mu na mudrosti i neizbrisivim sjećanjima koje nam je ostavio u baštinu. Nedostajat će nam njegov način razmišljanja, smisao za humor, miris njegove lule i njegovo prijateljstvo.

Ankica Marinović 